\title{
日本昆虫学会会誌“Entomological Science”目次
}

Vol. 20, 127-244

Zhao-yun LYU, Jun-rui ZHI, Yu-feng ZHOU, Ze-hong MENG and Juan WEN. Population genetic structure and migration patterns of Dendrothrips minowai (Thysanoptera: Thripidae) in Guizhou, China [Original Article].......

Sebastian BÜSSE, Philipp von GRUMBKOW, Janine MAZANEC, Gert TRÖSTER, Susanne HUMMEL and Thomas HÖRNSCHEMEYER. Note on using nuclear $28 S \mathrm{rDNA}$ for sequencing ancient and strongly

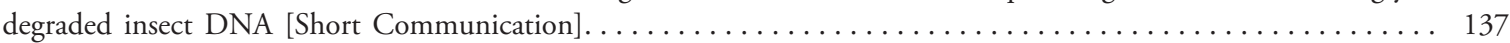

Lara Teixeira LARANJO and Ana Maria COSTA-LEONARDO. First record of intersex in neotenic reproductives

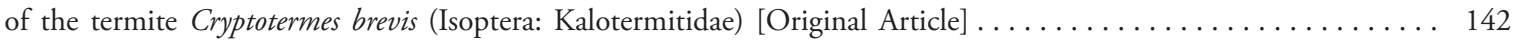

Akira YAMAWO, Yoshio HADA and Jun TAGAWA. Aggressiveness of ants attracted to the extrafloral nectarybearing plant, Mallotus japonicus, and temporal fluctuations in their abundance [Original Article] . . . . . . . 150

Ryoichi MIYANAGA, Yasuo MAETA, Fuminori ITO and Radha DEVKOTA ADHIKARI. Discovery of wood nesting by a subterranean halictine bee, Lasioglossum (Evylaeus) vulsum (Hymenoptera: Halictidae) [Short

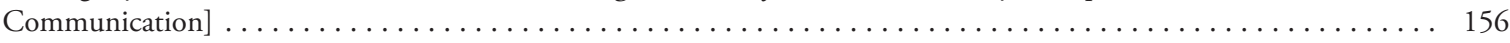

Kazuki SUGAYA, Ryo OGAWA and Yusuke HARA. Rediscovery of the "extinct" blind ground beetle (Coleoptera:

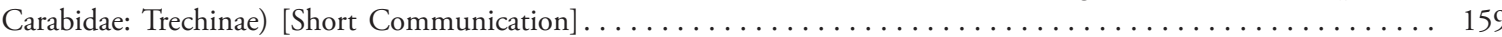

Shouhei HOSONO, Jun NAKAMURA and Masato ONO. European honeybee defense against Japanese yellow hornet using heat generation by bee-balling behavior [Original Article] .

Hugo Alejandro ÁLVAREZ, Juan Hector GARCÍA-CHÁVEZ and Jorge Alejandro CEBADA-RUIZ. Do social environments affect the use of exaggerated traits in the dobsonfly Corydalus bidenticulatus? [Original Article] . . . . . 168

Su LIU, Wen-Long WANG, Yu-Xing ZHANG, Bang-Xian ZHANG, Xiang-Jun RAO, Xiao-Ming LIU, DongMing WANG and Shi-Guang LI. Transcriptome sequencing reveals abundant olfactory genes in the antennae of

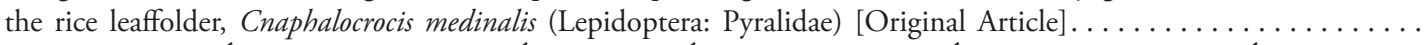

Jelica LAZAREVIĆ, Milena JANKOVIĆ-TOMANIĆ, Uroš SAVKOVIĆ, Mirko ĐORĐEVIĆ, Slobodan MILANOVIĆ and Biljana STOJKOVIĆ. Host-associated divergence in the activity of digestive enzymes in two populations of the gypsy moth Lymantria dispar (Lepidoptera: Erebidae) [Short Communication] . . . . . . . . . .

Hideki UENO, Naoyuki FUJIYAMA, Sih KAHONO, Sri HARTINI, Peter W. de JONG and Haruo KATAKURA. A solanum beetle on a fabaceous weed: Host plant generalization and specialization are two sides

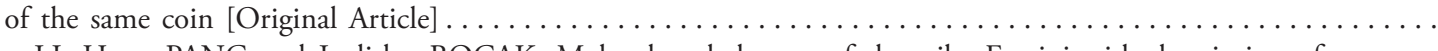

Yun LI, Hong PANG and Ladislav BOCAK. Molecular phylogeny of the tribe Erotini with description of a new genus from China (Coleoptera: Lycidae) [Original Article] $\ldots \ldots \ldots \ldots \ldots \ldots \ldots \ldots \ldots \ldots \ldots \ldots \ldots \ldots \ldots \ldots$

Kouhei MURATA and Morimasa TSUCHIYA. Structure of the food web including the endangered lycaenid butterfly Shijimiaeoides divinus asonis (Lepidoptera: Lycaenidae) [Original Article] . . . . . . . . . . . . . . 224

Jacobo RÚA, José Manuel TIERNO DE FIGUEROA and Josefina GARRIDO. Contribution to the knowledge of the adult feeding of Nemouroidea stoneflies (Insecta: Plecoptera) [Original Article] . . . . . . . . . . . . . . 235 